\title{
Interaksjoner mellom metoprolol og antidepressive legemidler
}

\begin{abstract}
Sammendrag
Bakgrunn. Metoprolol, som er den mest brukte betablokkeren i Norge, elimineres primært via cytokrom P450 (CYP) 2D6. Dette er et enzym som i varierende grad hemmes av ulike antidepressive legemidler. Hensikten med denne artikkelen er å gi en oversikt over interaksjoner mellom antidepressiver og metoprolol med særlig vekt på CYP2D6-hemming.
\end{abstract}

Materiale og metode. Relevant litteratur ble identifisert ved søk i PubMed med søkeord «metoprolol» kombinert med navn på nyere antidepressive legemidler.

Resultater. Paroksetin er vist å øke biologisk tilgjengelig dose av metoprolol i størrelsesorden 4-6 ganger. Det samme vil trolig gjelde de to andre potente CYP2D6-hemmerne i samme gruppe, fluoksetin og bupropion. Det er publisert tilfeller med alvorlig bradykardi og AV-blokk ved kombinasjon av metoprolol og disse tre midlene. Escitalopram, citalopram og duloksetin er mindre potente CYP2D6-hemmere, som er vist å gi 2-3 ganger økning i biologisk tilgjengelig metoprololdose. Sertralin, venlafaksin, mianserin og mirtazapin forårsaker begrenset eller ingen hemming av CYP2D6 og forventes ikke å gi klinisk relevante interaksjoner med metoprolol.

Fortolkning. Metoprolol bør generelt ikke brukes sammen med paroksetin, fluoksetin eller bupropion grunnet fare for alvorlige bivirkninger. Dosereduksjon bør vurderes ved samtidig behandling med metoprolol og citalopram, escitalopram eller duloksetin. Kombinasjon med sertralin, venlafaksin, mianserin og mirtazapin anses som uproblematisk.

\section{Espen Molden}

emolden@farmasi.uio.no

Farmasøytisk institutt

Universitetet i Oslo

og

Senter for Psykofarmakologi

Diakonhjemmet sykehus

\section{Olav Spigset}

Avdeling for klinisk farmakologi

St. Olavs hospital

og

Institutt for laboratoriemedisin,

barne- og kvinnesykdommer

Norges teknisk-naturvitenskapelige universitet

Betablokkere har en sentral plass i behandlingen av en rekke kardiovaskulære tilstander, inklusive hypertensjon, angina pectoris, arytmier og hjertesvikt. I Norge er det ca. 250000 personer som bruker metoprolol daglig, hvorav halvparten er over 70 år (1). Metoprolol er en selektiv hemmer av adrenerge beta $_{1}$-reseptorer. Doseavhengige bivirkninger av metoprolol omfatter bl.a. slapphet, kalde hender og føtter, urolig søvn, impotens, bradykardi og AV-blokk. Hjertesvikt kan også utløses eller forverres hvis systemisk eksponering blir for høy.

Omsetningen av metoprolol skjer i stor grad via enzymet cytokrom P450 (CYP) 2D6. Dette enzymet utviser genetisk betinget variasjon i aktiviteten. Ca. 5-10\% av personer av kaukasisk (vesteuropeisk) avstamning har en homozygot defekt i CYP2D6-funksjonen og er såkalte langsomme omsettere. Disse har en øt risiko for bivirkninger, spesielt bradykardi, ved bruk av anbefalte doser metoprolol $(2,3)$. For den resterende delen av befolkningen - de som har funksjonell CYP2D6-metabolisme - innebærer bruk av metoprolol sammen med legemidler som hemmer CYP2D6, en risiko for forhøyet plasmakonsentrasjon av metoprolol og økt fare for bivirkninger. Flere antidepressive legemidler har egenskaper som CYP2D6-hemmere. Hensikten med denne artikkelen er å gi en oversikt over i hvilken grad ulike antidepressiver interagerer med metoprolol.

\section{Materiale og metode}

Relevant litteratur ble identifisert ved søk i PubMed med kombinasjon av ordene «metoprolol» og navn på ulike nyere antidepressiver. Søkene ble låst til «title/abstract» $\mathrm{i}$ PubMed med følgende informasjon: «metoprolol AND (paroxetine OR fluoxetine OR sertraline OR citalopram OR escitalopram OR bupropion OR venlafaxine OR duloxetine OR mirtazapine OR mianserin)».

Både interaksjonsstudier og kasusrapporter ble inkludert i litteraturgjennomgangen. Informasjonen som ble hentet ut fra publikasjonene inkluderte relativ økning i plasmakonsentrasjon (systemisk eksponering) av metoprolol ved samtidig bruk av respektive antidepressiver, samt eventuell påvirkning på kliniske variabler som blodtrykk og puls.

\section{Resultater}

Totalt ble åtte studier/rapporter som belyser interaksjonsrisiko mellom metoprolol og antidepressiver identifisert (4-11). Tabell 1 oppsummerer hovedfunn fra disse publikasjonene. Informasjon om forsøkspersonenes/pasientenes CYP2D6-metaboliserende evne (genetisk betinget) manglet i de fleste publikasjonene og er ikke omtalt i tabellen.

For kombinasjonen metoprolol og paroksetin ble det funnet tre interaksjonsstudier (4-6). Den første studien viste 5-6 ganger økning i plasmakonsentrasjonen av metoprolol etter en engangsdose gitt til friske forsøkspersoner (4). Det var en signifikant sterkere farmakodynamisk effekt av metoprolol i kombinasjon med paroksetin enn kombinert med placebo (4). Blant annet ble treningsindusert pulsøkning redusert med $30-40 \% \mathrm{i}$ kombinasjon med paroksetin (4). Interaksjonen mellom metoprolol og paroksetin er senere blitt bekreftet i en studie på hjertepasienter, der plasmakonsentrasjonen av metoprolol økte drøyt fire ganger (5). Også i denne studien ble økningen ledsaget av en

\section{Hovedbudskap}

- Mange pasienter med indikasjon for metoprololbehandling lider også av depresjon

- Paroksetin, fluoksetin eller bupropion bør ikke brukes hos pasienter stabilisert på metoprolol pga. fare for alvorlige bivirkninger av metoprolol

- I kombinasjon med citalopram, escitalopram eller duloksetin bør metoprololdosen reduseres for å unngå bivirkninger

- Andre antidepressiver kan kombineres med metoprolol uten risiko for interaksjoner 
Tabell 1 Oversikt over publikasjoner som belyser interaksjonsrisiko mellom metoprolol og antidepressive legemidler

\begin{tabular}{|c|c|c|}
\hline Antidepressivum & Publikasjonstype & Metoprololpåvirkning \\
\hline Paroksetin & Interaksjonsstudie (4) & $\begin{array}{l}\text { Mer enn } 5 \text { ganger } ø \text { kning i metoprololkonsentrasjonen, } 30-40 \% \text { lavere treningsindusert } \\
\text { pulsøkning hos friske fors } \varnothing k s p e r s o n e r ~(p<0,01)\end{array}$ \\
\hline Paroksetin & Interaksjonsstudie (5) & $\begin{array}{l}\text { 4-5 ganger økning i metoprololkonsentrasjonen, ca. } 15 \% \text { lavere hvilepuls hos hjertepasienter } \\
(p<0,001)\end{array}$ \\
\hline Paroksetin & Interaksjonsstudie (6) & $\begin{array}{l}4-5 \text { ganger økning i metoprololkonsentrasjonen ved vanlig tablett mot 3-4 ganger økning } \\
\text { ved depottablett }{ }^{1}\end{array}$ \\
\hline Paroksetin & Kasusrapport (7) & $\begin{array}{l}\text { Bradykardi etter oppstart av paroksetin hos pasient behandlet med metoprolol (hjertefrekvens } \\
41 \text { slag/minutt) }\end{array}$ \\
\hline Paroksetin & Kasusrapport (8) & AV-blokk grad III etter oppstart av paroksetin hos pasient stabilisert på metoprolol \\
\hline Fluoksetin & Kasusrapport (9) & $\begin{array}{l}\text { Bradykardi etter oppstart av fluoksetin hos pasient stabilisert på metoprolol (hjertefrekvens } \\
36 \mathrm{slag} / \text { minutt) }\end{array}$ \\
\hline Bupropion & Kasusrapport (10) & $\begin{array}{l}\text { Bradykardi etter oppstart av bupropion hos pasient stabilisert på metoprolol (hjertefrekvens } \\
43 \mathrm{slag} / \text { minutt) }\end{array}$ \\
\hline Duloksetin & Interaksjonsstudie (11) & Ca. 3 ganger økning i metoprololkonsentrasjonen ${ }^{1}$ \\
\hline Escitalopram & Interaksjonsstudie (11) & Ca. 2 ganger økning i metoprololkonsentrasjonen ${ }^{1}$ \\
\hline Sertralin & Interaksjonsstudie (11) & Ca. 1,5 ganger økning i metoprololkonsentrasjonen ${ }^{1}$ \\
\hline
\end{tabular}

signifikant reduksjon i hjertefrekvens, i størrelsesorden $15 \%$ (5). Hos to av de i alt 17 deltakerne måtte metoprololdosen reduseres pga. bradykardi og ortostatisk hypotensjon (5). I en tredje interaksjonsstudie mellom metoprolol og paroksetin undersøkte man betydningen av metoprololformulering for interaksjonsgrad med paroksetin (6). Denne studien viste at økningen i plasmakonsentrasjonen av metoprolol var noe mindre ved bruk av depotformulering sammenliknet med vanlig tablettformulering, men økningen var også kraftig med depotformuleringen - i størrelsesorden 3-4 ganger (6).

I tillegg ble det funnet to kasusrapporter der det oppsto alvorlige bivirkninger av metoprolol etter oppstart av behandling med paroksetin $(7,8)$. Den ene pasienten fikk bradykardi (7), mens den andre fikk AV-blokk grad III (8). Tilsvarende tilfeller er også rapportert etter oppstart av fluoksetin og bupropion (9, 10), men det er ikke gjort farmakokinetiske interaksjonsstudier med metoprolol i kombinasjon med de to sistnevnte.

I en annen interaksjonsstudie ble effekten av duloksetin, escitalopram og sertralin på plasmakonsentrasjonen av metoprolol sammenliknet (11). Resultatene viste signifikante økninger i plasmakonsentrasjon av metoprolol (nær en tredobling) ved samtidig behandling med duloksetin, sammenliknet med ca. 2 ganger ved bruk av escitalopram og ca. 1,5 ganger ved bruk av sertralin (11).

\section{Diskusjon}

Her til lands behandles rundt 250000 personer med metoprolol, mens mer enn 300000 personer årlig får forskrevet et antidepressivt legemiddel (1). Det er derfor sannsynlig at mange norske pasienter behandles med antidepressiver i kombinasjon med metoprolol. Denne oversiktsartikkelen viser at enkelte antidepressiver kan gi en betydelig økning i systemisk tilgjengelig dose av metoprolol. Flere studier har vist en kraftig interaksjon mellom paroksetin og metoprolol, med økning i plasmakonsentrasjonen av sistnevnte i størrelsesorden 4-6 ganger (4-6). Det betyr i praksis at én tablett metoprolol forsterkes til 4-6 tabletter i kombinasjon med paroksetin. Det er derfor ikke overraskende at det er rapportert både alvorlig bradykardi og AV-blokk ved kombinert bruk av metoprolol og paroksetin $(7,8)$.

Fluoksetin og bupropion er to andre antidepressiver med omtrent like sterke CYP2D6hemmende egenskaper som paroksetin. $\mathrm{Vi}$ fant ingen studier der man hadde undersøkt $\mathrm{i}$ hvilken grad fluoksetin og bupropion interagerer med metoprolol. Men ut fra studier med andre CYP2D6-substrater $(12,13)$, er det all grunn til å tro at også fluoksetin og bupropion vil øke systemisk dose av metoprolol i tilsvarende grad som paroksetin. Dette støttes av to kasusrapporter, der svært lav hjertefrekvens ble observert ved bruk av metoprolol i kombinasjon med henholdsvis fluoksetin og bupropion $(9,10)$. Med tanke på den kraftige og til dels uforutsigbare interaksjonseffekten, bør derfor behandling med paroksetin, fluoksetin og bupropion unngås hos pasienter som bruker metoprolol.

Duloksetin er et relativt nytt antidepressivum som også har CYP2D6-hemmende egenskaper. I kombinasjon med metoprolol økte plasmakonsentrasjonen av metoprolol nærmere tre ganger (11). Selv om dette indikerer at hemmingen av CYP2D6 er mindre for duloksetin enn for paroksetin, fluoksetin og bupropion, må interaksjonen mellom duloksetin og metoprolol betraktes som så kraftig at den kan resultere i betydelig økt risiko for bivirkninger av sistnevnte. Det er derfor all grunn til også å ta interaksjonen mellom duloksetin og metoprolol på alvor.

Når det gjelder escitalopram, ble det ob- servert en dobling i systemisk nivå av metoprolol (11). Denne interaksjonsgraden vil mange pasienter tolerere, men samtidig er det vanskelig å være likegyldig til om en pasient får én eller to tabletter av et legemiddel. Det er derfor grunn til å følge opp pasienten med tanke på eventuelle overdoseringssymptomer/bivirkninger av metoprolol ved kombinasjonsbehandling med escitalopram. Effekten av citalopram forventes å være den samme, slik at tilsvarende forholdsregler bør tas også ved kombinasjonsbehandling med citalopram. Blant undersøkte antidepressiver var relativ økning i plasmakonsentrasjon av metoprolol minst for sertralin, dvs. ca. $50 \%$ (11). Dette er en interaksjonsgrad som generelt ikke forventes å medføre noen endring i klinisk respons av metoprolol.

$\mathrm{Vi}$ fant ingen studier eller rapporter der farmakokinetisk eller farmakodynamisk påvirkning på metoprolol var blitt undersøkt i kombinasjon med venlafaksin, mianserin eller mirtazapin. I andre studier er disse antidepressivene vist ikke å inneha CYP2D6hemmende egenskaper $(12,14)$. Ut fra dette er det sannsynlig at bruk av venlafaksin, mianserin eller mirtazapin sammen med metoprolol ikke innebærer noen risiko for klinisk relevante interaksjoner. For å unngå ugunstige interaksjoner bør derfor en av disse tre midlene, alternativt sertralin, som er den selektive serotoninreopptakshemmeren med minst interaksjonsrisiko, foretrekkes ved behov for antidepressiv behandling hos pasienter som er stabilisert på metoprolol.

I tilfeller der pasienter som er under stabil og vellykket behandling med CYP2D6-hemmende antidepressiver, skal starte betablokkerbehandling, kan et alternativ være å bruke en betablokker som ikke metaboliseres av CYP2D6, som f.eks. atenolol eller bisoprolol. Disse har imidlertid delvis andre farmakologiske egenskaper enn metoprolol og har 
dårligere klinisk dokumentasjon for visse indikasjoner. Det vil derfor i noen situasjoner være ønskelig å starte med metoprolol til tross for interaksjonsrisiko med antidepressive legemidler. For å unngå bivirkninger bør man da forsøke å tilpasse dosen av metoprolol for å kompensere for interaksjonen.

Dersom gjennomsnittsdata for interaksjonsgrad i kliniske studier legges til grunn, kan et generelt råd være å dosere metoprolol rundt $75-80 \%$ lavere i kombinasjon med de mest potente CYP2D6-hemmerne (paroksetin, fluoksetin eller bupropion), dvs. en firedel til en femdel av vanlig anbefalt dosering ved aktuell indikasjon. For citalopram, duloksetin og escitalopram, som er en mer moderate CYP2D6-hemmere, vil anslagsvis dosereduksjonen av metoprolol ligge i størrelsesområde $50-70 \%$, dvs. halvparten til en tredel av vanlig anbefalt dosering. Et viktig poeng når det gjelder dosejustering, er imidlertid at interaksjonsgrad vil variere mye fra person til person, blant annet grunnet genetiske forskjeller i CYP2D6-metabolisme. Det er derfor viktig at kliniske variabler som puls og blodtrykk uansett følges nøye hvis metoprolol kombineres med interagerende antidepressiver.

\section{Konklusjon}

Kombinert bruk av metoprolol og antidepressiver kan innebære en betydelig risiko for alvorlige bivirkninger av metoprolol, bl.a. kraftig bradykardi og AV-blokk, som en følge av interaksjoner via CYP2D6-hemming. Paroksetin, fluoksetin og bupropion er de mest potente hemmerne. Samtidig bruk av med en av disse legemidlene vil anslagsvis øke systemisk tilgjengelig dose av metoprolol med i gjennomsnitt 5 ganger, men det vil være store individuelle forskjeller. Kombinasjonsbehandling bør derfor unngås i den grad det er mulig, eventuelt med unntak av at en svært forsiktig oppstart med metoprolol hos en pasient som bruker et av disse midlene fra før kan være en mulighet. Til sammenlikning kan man forvente rundt en tredobling og fordobling av metoprololnivåene i kombinasjon med hhv. duloksetin og escitalopram/citalopram. Sertralin, venlafaksin, mianserin og mirtazapin forventes ikke å påvirke metoprolol i relevant grad, og bør være foretrukne antidepressiver i kombinasjon med metoprolol ut fra et interaksjonsperspektiv.

\section{Espen Molden (f. 1972)}

er cand. pharm. og professor ved Farmasøytisk institutt, Universitetet i Oslo og enhetsleder for forskning ved Senter for Psykofarmakologi, Diakonhjemmet sykehus.

Oppgitte interessekonflikter: Har mottatt honorar fra Apotekforeningen for utarbeiding av interaksjonsdatabasen APRIORI til apotekenes programvare (FarmaPro), og fra Statens legemiddelverk for utvikling av interaksjonsmodulen i FEST-programvaren.

\section{Olav Spigset (f. 1963)}

er dr.med. og spesialist i klinisk farmakologi. Han er seksjonsoverlege ved Avdeling for klinisk farmakologi, St. Olavs hospital, og professor i klinisk farmakologi ved Norges teknisknaturvitenskapelige universitet. Oppgitte interessekonflikter: Har mottatt honorar for å utarbeide de generelle kapitlene om interaksjoner i Felleskatalogen og Norsk legemiddelhåndbok, samt for å utvikle og vedlikeholde databasen DRUID og interaksjonsmodulen i Statens legemiddelverks FEST-programvare. Mottar royalties fra DRUID for inntekter som DRUID har fra salg av lisenser for inkorporering av DRUID i pasientjournal-programvare etc.

Litteratur

1. Reseptregisteret. www.reseptregisteret.no (28.3.2011).

2. Wuttke H, Rau T, Heide R et al. Increased frequency of cytochrome P450 2D6 poor metabolizers among patients with metoprolol-associated adverse effects. Clin Pharmacol Ther 2002; 72: 429-37.

3. Bijl MJ, Visser LE, van Schaik RH et al. Genetic variation in the CYP2D6 gene is associated with a lower heart rate and blood pressure in betablocker users. Clin Pharmacol Ther 2009; 85: 45-50.

4. Hemeryck A, Lefebvre RA, De Vriendt $C$ et al. Paroxetine affects metoprolol pharmacokinetics and pharmacodynamics in healthy volunteers. Clin Pharmacol Ther 2000; 67: 283-91.

5. Goryachkina K, Burbello A, Boldueva S et al. Inhibition of metoprolol metabolism and potentiation of its effects by paroxetine in routinely treated patients with acute myocardial infarction (AMI). Eur J Clin Pharmacol 2008; 64: 275-82.

6. Stout SM, Nielsen J, Welage LS et al. Influence of metoprolol dosage release formulation on the pharmacokinetic drug interaction with paroxetine. J Clin Pharmacol 2011; 51: 389-96.

7. König F. Häfele M, Hauger B et al. Bradycardia after beginning therapy with metoprolol and paroxetine. Psychiatr Prax 1996; 23: 244-5.

8. Onalan O, Cumurcu BE, Bekar L. Complete atrioventricular block associated with concomitant use of metoprolol and paroxetine. Mayo Clin Proc 2008; 83: 595-9.

9. Walley T, Pirmohamed M, Proudlove $C$ et al. Inter action of metoprolol and fluoxetine. Lancet 1993; 341: $967-8$.

10. McCollum DL, Greene JL, McGuire DK. Severe sinus bradycardia after initiation of bupropion therapy: a probable drug-drug interaction with metoprolol. Cardiovasc Drugs Ther 2004; 18: 329-30

11. Preskorn SH, Greenblatt DJ, Flockhart D et al. Comparison of duloxetine, escitalopram, and sertraline effects on cytochrome $\mathrm{P} 4502 \mathrm{D} 6$ function in healthy volunteers. J Clin Psychopharmacol 2007; 27: 28-34.

12. Amchin J, Ereshefsky L, Zarycranski W et al. Effect of venlafaxine versus fluoxetine on metabolism of dextromethorphan, a CYP2D6 probe. J Clin Pharmacol 2001; 41: 443-51

13. Güzey C, Norström $\AA$, Spigset 0 . Change from the CYP2D6 extensive metabolizer to the poor metabo lizer phenotype during treatment with bupropion. Ther Drug Monit 2002; 24: 436-7.

14. Remeron SPC. www.legemiddelverket.no (28.3.2011).

Mottatt 31.1. 2011, første revisjon innsendt 9.5. 2011, godkjent 19.5. 2011. Medisinsk redaktør Petter Gjersvik. 